\title{
ENGLISH FOR BUSINESS PURPOSES: SPECIALIZED TRANSLATION IN DEVELOPING AN ENGLISH-SERBIAN GLOSSARY OF RISK MANAGEMENT TERMS IN BANKING
}

\author{
UDC 811.111'276.6:336.7 \\ $811.111^{\prime} 255: 811.163 .41$
}

\begin{abstract}
Aleksandar M. Jagrović, Biljana Č. Jagrović
University of Novi Sad, Faculty of Agriculture, Department of Agricultural Economics, Novi Sad, Serbia
\end{abstract}

\begin{abstract}
The purpose of this paper is to describe the process of developing an EnglishSerbian glossary of risk management terms in banking with an emphasis on the specialized translation procedures utilized therein. Upon completion of the source material content and contrastive analysis (using the Atlas.ti 7 program), a corpus of 513 English terms (ETs) and 859 Serbian (one-to-one and/or one-to-many) translation equivalents (STEs) was collated and ethnographically verified at Vojvođanska Bank (Vojvođanska banka a.d. Novi Sad) in order to achieve a triangulation of the data sources and research methods. The overall prevalence of each translation procedure employed in the glossary was computed individually and in combination with other procedures in the following order: calque $(49.64 \%)$, borrowing $(32.45 \%)$, reordering $(24.59 \%)$, equivalence $(22.41 \%)$, transposition (14.73\%), diffusion (13.46\%), expansion (10.52\%), literal translation $(9.21 \%)$, adaptation $(7.32 \%)$, modulation $(4.68 \%)$, reduction $(3.67 \%)$ and condensation $(2.19 \%)$. The results obtained reflect the underlying trends in the specialized English-Serbian translation of risk management terms in banking, serving as reference guidelines for linguists, lexicographers and translators in their future research and practice. The present glossary is available in entirety and with open access on the self-created web page ESGRMTB.
\end{abstract}

Key words: English for business purposes, English-Serbian glossary, specialized translation, risk management, banking

\footnotetext{
Submitted February $17^{\text {th }} 2017$, accepted for publication April 21 $1^{\text {st }}, 2017$

Corresponding author: Aleksandar M. Jagrović

University of Novi Sad, Faculty of Agriculture, Department of Agricultural Economics, Novi Sad, Serbia

E-mail: jagrovicalex@gmail.com
} 


\section{INTRODUCTION}

English for business purposes (EBP) is the lingua franca of international business communication and one of the most salient $\mathrm{ESP}^{1}$ specialisms. Originating as a materialsdriven and learner-centred (needs-responsive) pedagogic movement (St John 1996: 15), EBP has traversed a strenuous journey to the contemporary research-led, praxis-based and ethnographic (social-use-centred) pedagogy (Belcher 2009: 1-20; Starfield 2010: 138-46; Hyland 2006: 66), which develops Business English through an interdisciplinary approach encompassing fields such as applied linguistics, corpus linguistics, pragmatics, discourse analysis, ethnomethodology, sociolinguistics, etc. Consequently, the divisive gap between the EBP pedagogy and real-world, culture-bound business interactions has been bridged to a notable extent. One of such efforts is determining the ESP specificity as 'wide-angled' (for a more generic literacy) or 'narrow-angled' (for a more subject-specific literacy) with regard to the target audience (Basturkmen 2010: 52). Although the terms 'wideand narrow-angled' may imply a dichotomous division, ESP specialisms and sub-specialisms can be discerned on 'a continuum of specificity' (Basturkmen 2010: 53), ranging from the most general such as Business English, through less general and more specific such as English for Banking, to very specific such as English for Risk Management in Banking and even ultimately specific such as English for Risk Management in Banking at Vojvođanska Bank (Vojvođanska banka a.d. Novi Sad).

Risk management in banking is a highly specialized field of banking which addresses actual and potential, financial and non-financial risks a bank might assume in order to maximize profitability and shareholder value. The process entails laborious activities such as risk identification, risk measurement (or assessment), risk reporting, risk monitoring and risk management in the narrow sense (i.e. the selection of appropriate measures for managing risk exposures) (Allen 2013: 29-45; Ho \& Lee 2006: 491; Gramling 2001: 488; Bessis: 1-13). Banks are highly susceptible to numerous and various risks such as credit, market, operational, exposure, liquidity, investment, sovereign, legal, strategic, reputational, model, contagion and cyber risks (Härle et al.: 3-19; Carey \& Stulz: 7-12; Lauer et al.: 1-13; Hull: 119, Uyemura \& Deventer: 5; NBS 2016). Risk can be incurred at any level of banking and business operations. Since many differing terms and concepts exist in relation to risk management in banking, their interpretation and especially translation can prove to be an insurmountable impediment to business communication with unforeseen ramifications.

The purpose of this paper is to describe the process of developing an English-Serbian glossary of risk management terms in banking with an emphasis on the specialized translation procedures employed therein. A rapid and extensive expansion of banking (characterized by computing, online information sharing and perpetually changing regulatory and social contexts) engenders a demand for an authoritative English-Serbian source of fundamental banking risk management terms, inasmuch as such volumes are virtually non-existent in the contemporary Serbian, British and American lexicography. The English-Serbian Glossary of Risk Management Terms in Banking presented in this paper is designed as a subjectspecific advanced guide for working professionals engaged in the fields of banking and finance. The glossary will indubitably facilitate and enhance business communication within and across both profit-motivated enterprises and non-profit organizations, as well as the banking and financial sectors as a whole. Moreover, it could be the predecessor to a large-

${ }^{1}$ ESP: English for Specific Purposes 
scale prospective volume, such as an English-Serbian dictionary of risk management terms in banking, and a reference guide to the specialized English-Serbian translation in banking by virtue of the translation procedures utilized and argued.

\section{MATERIALS, Methods AND STRUCTURE OF THE ENGLISH-SERBIAN GLOSSARY OF RISK MANAGEMENT TERMS IN BANKING}

The lexical units in English as the source language (SL) were collated from the following variety of primary source materials: the Basel II and III Accords ${ }^{2}$ (the banking supervision accords, i.e. the recommendations on banking regulations, issued by the Basel Committee on Banking Supervision (BCBS)), The Dictionary of Financial Risk Management (Gastineau \& Kritzman 1999) and The Glossary of Insurance and Risk Management Terms (IRMI 2016) (the most comprehensive and up-to-date online English glossary of risk management terms). A total of 513 English terms (ETs) are pertinent to risk management in banking and highly prone to misinterpretation and mistranslation. Therefore, general reference business terms (such as committee, supervisor, leasing agent, etc.) and the ones which pose no vexing issues in interpretation and translation (such as credit protection, export credit, denominated, etc.) were excluded in the selection process. A total of 859 (one-to-one and/or one-to-many) translation equivalents in Serbian as the target language (TL) were collated from the following primary source materials: the NBS (the National Bank of Serbia) officially accepted and standardized translation of the aforementioned Basel II and III documents ${ }^{3}$, Poslovni rečnik: engleskosrpski srpsko-engleski (Cvejić 2006) and Englesko-srpski ekonomsko-finansijski rečnik (Simurdić 2004).

The content analysis of the primary source materials was performed using the Atlas.ti 7 program for qualitative data analysis. The Atlas.ti HU editor enabled a simultaneous contrastive analysis of the materials by opening and comparing multiple documents in parallel (both in English and/or Serbian). The multi-document view facilitated the linking of documents by dragging and dropping a selected banking risk management term in English (such as accrued interest) or its Serbian translation equivalent (narasla kamata) between the texts to create a hyperlink in Atlas.ti 7. This hyperlink, i.e. the relation between the documents, was labelled with the selected term itself, or its Serbian translation equivalent, and thus the presence of the term and/or the translation equivalent in all the documents analysed was confirmed (or refuted) and contextually studied (which is of overriding importance to one-to-many translation equivalents as they are quintessentially contextbound). Furthermore, upon completion of the source material content and contrastive analysis, each specialist English term and its potential Serbian translation equivalent(s) were empirically and ethnographically verified by practicing Risk Officers at Vojvođanska Bank (by means of direct communication and observation in the workplace for a

\footnotetext{
${ }^{2}$ Basel II: The International Convergence of Capital Measurement and Capital Standards: A Revised Framework (BCBS 2006); Basel III: A Global Regulatory Framework for More Resilient Banks and Banking Systems - Revised Version (BCBS 2011), Basel III: The Liquidity Coverage Ratio and Liquidity Risk Monitoring Tools (BCBS 2013) and Basel III: The Net Stable Funding Ratio (BCBS 2014);

${ }^{3}$ Bazel II: Međunarodna saglasnost o merenju kapitala i standardima kapitala (Kovačević, ed., 2007), Bazel III: Globalni regulatorni okviri i standardi (Kovačević, ed., 2012) and Bazel III: Međunarodni okvir za merenje rizika likvidnosti, standarde i monitorisanje (Kovačević, ed., 2014)
} 
sustained period of time exceeding two years), which overall resulted in a triangulation of the data sources and research methods employed.

The glossary is designed as a tabular representation of the collated English risk management terms in banking, their synonyms (if any), specialized Serbian translation equivalents (STEs) and specific definitions in English (Table 1). The English entries are listed in alphabetically ordered base forms. The lexical and grammatical categories of entries are (if necessary) marked accordingly with the following abbreviations: $n$. (noun), $v$. (verb), adj. (adjective), NP (noun phrase), sg. (singular) and $p l$. (plural). The Serbian translation equivalents are ordered and numbered either according to the difference in translation (e.g. the ET account churning and its STEs: 1) zamena računa; 2) miksanje; prekomerno trgovanje (na računu klijenta)) or the accuracy and frequency of translation (e.g. the ET affiliate company and its STEs: 1) podružnica; 2) preduzeće-ćerka; 3) afilijacija). The definitions of English terms are provided via active links to the most comprehensive open-access specialized English dictionaries (such as Online Business Dictionary, Financial Dictionary Investopedia, InvestorWords, The Free Dictionary, etc.) to assure maximum time efficiency and availability to users.

Table 1 A sample tabular representation of the English-Serbian glossary of risk management terms in banking

\begin{tabular}{|c|c|c|c|}
\hline English term & $\begin{array}{l}\text { English } \\
\text { synonym(s) }\end{array}$ & $\begin{array}{l}\text { Serbian translation } \\
\text { equivalent(s) }\end{array}$ & Definition(s) in English \\
\hline account churning & $\begin{array}{l}\text { overtrading } \\
\text { (securities) }\end{array}$ & $\begin{array}{l}\text { 1) zamena računa } \\
\text { (bankarstvo); } \\
\text { 2) miksanje; prekomerno } \\
\text { trgovanje (na računu klijenta) } \\
\text { (hartije od vrednosti; berza) }\end{array}$ & $\begin{array}{l}\text { http://www.businessdictionary. } \\
\text { com/definition/churning.html }\end{array}$ \\
\hline $\begin{array}{l}\text { account take-over } \\
\text { account takeover }\end{array}$ & - & 1) uzurpacija računa & $\begin{array}{l}\text { http://www.macmillandictionar } \\
\text { y.com/dictionary/british/accou } \\
\text { nt-take-over }\end{array}$ \\
\hline accrued interest & $\begin{array}{l}\text { active assets } \\
\text { surplus }\end{array}$ & $\begin{array}{l}\text { 1) narasla / neisplaćena } \\
\text { kamata; }\end{array}$ & $\begin{array}{l}\text { http://www.investopedia.com/t } \\
\text { erms/a/accruedinterest.asp }\end{array}$ \\
\hline actual loss & - & $\begin{array}{l}\text { 1) nastali gubitak; } \\
\text { 2) stvarni gubitak; aktuelni } \\
\text { gubitak }\end{array}$ & $\begin{array}{l}\text { http://www.businessdictionary. } \\
\text { com/definition/actual-loss.html }\end{array}$ \\
\hline adjusted exposure & - & 1) korigovana izloženost & $\begin{array}{l}\text { http://riskarticles.com/credit- } \\
\text { risk-how-to-calculate- } \\
\text { expected-loss-unexpected-loss/ }\end{array}$ \\
\hline $\begin{array}{l}\text { affiliate company } \\
\text { affiliated company }\end{array}$ & $\begin{array}{l}\text { associate } \\
\text { company; } \\
\text { affiliate }\end{array}$ & $\begin{array}{l}\text { 1) podružnica; } \\
\text { 2) preduzeće-ćerka; } \\
\text { 3) afilijacija }\end{array}$ & $\begin{array}{l}\text { http://www.investopedia.com/t } \\
\text { erms/a/affiliatedcompanies.asp }\end{array}$ \\
\hline
\end{tabular}

\section{SPECIALIZED ENGLISH-SERBIAN TRANSLATION OF THE GLOSSARY TERMS}

The translation procedures argued by Jean-Paul Vinay and Jean Darbelnet in their seminal work Comparative Stylistics of French and English (1995) (namely borrowing, calque, literal translation, transposition, modulation, equivalence and adaptation) incorporate the fundamental principles of translation and form the basis of specialized 
English-Serbian translation ${ }^{4}$ in the glossary. These procedures are discernible on a continuum that is gradually shifting from 'direct' or literal translation (borrowing, calque and literal translation) towards 'oblique' or free translation (transposition, modulation, equivalence and adaptation) (Vinay \& Darbelnet 1995: 30-41). They are frequently used individually and/or in combination either with each other or additional (supplementary and complementary) procedures as argued by other authors, namely Newmark (expansion and reduction (1995: 90)) and Malone (diffusion, condensation and reordering (1988: 18)).

Borrowing is the transfer of SL words to the TL usually without morpho-syntactic and lexico-semantic modifications (Bell 1991: 70). Borrowed words are called loanwords, and they are a common occurrence particularly in specialized translation. Peter Newmark distinguishes between transferring a lexical unit in the original SL form (e.g. underwriting often remains intact in Serbian banking texts) and adapting it to the phonological, morphological and orthographic norms of the TL, which he labels 'transliteration' (1995: 81) (e.g. ritejl) as displayed in Table 2. The main reason for borrowing is 'to fill a semantic gap in the TL' or to add 'a local colour' by retaining SL words and using a language that is considered to be more exotic, fashionable, colourful and unusual (Munday 2001: 56).

Borrowing with transliteration features various degrees of TL adaptation (the full TL adaptation: the ET futures and its STE fjučersi; the partial TL adaptation: the ET insolvency and its STE insolventnost (as opposed to nesolventnost), which retained the English prefix inwhile the English suffix - $c y$ was replaced with the Serbian -ost). Borrowing without transliteration either involves a direct transmission of the whole term from the SL to the TL 'with zero adaptation' (Hlebec 2009: 15), which is often and preferably italicized in the TL (e.g. cross-default, in the money, marking-to-market, etc.), or a combination of SL borrowing and TL adaptation (when hybrids such as take-out finansiranje and escrow račun are created). Moreover, borrowing frequently co-occurs with calques (e.g. call option = kol opcija, convertible bonds $=$ konvertibilne obveznice, venture capital $=$ venčer kapital, etc.). Borrowing with and without transliteration is fairly frequent in specialized banking genres, and it accounts for $32.45 \%$ of the STEs examined.

Table 2 The glossary examples of English-Serbian borrowing with and without transliteration

\begin{tabular}{llll}
\hline English term & $\begin{array}{l}\text { Serbian translation equivalent } \\
\text { borrowing } \\
\text { (with transliteration) }\end{array}$ & & $\begin{array}{l}\text { Serbian translation } \\
\text { equivalent - borrowing } \\
\text { (without transliteration) }\end{array}$ \\
\hline appreciation & apresijacija & cross-default & cross-default \\
back office & bek ofis & escrow account & escrow račun \\
back-testing & bek-testing; bektesting & floor & floor \\
clean-up & klinap & in the money & in the money \\
compliance & komplajans & marking-to-market & marking-to-market \\
futures & fjučersi & OTC derivative & OTC derivat \\
goodwill & gudvil & out-of-the money & out-of-the money \\
insolvency & insolventnost; nesolventnost & swaption & swaption \\
\hline
\end{tabular}

\footnotetext{
${ }^{4}$ The genre-based classifications of translation throughout the history have either been dyadic (literary and non-literary translation (Schäffner 2004: 62; Cao 2007: 7; Rogers \& Anderman 2003: 57); general and specialized translation (Roberts 1995: 73); sci-tech and socio-eco-political translation (Roberts 1995: 73)) or tripartite (general, literary and specialist translation (Snell-Hornby 1995: 17-25); scientific-technological, institutional-cultural and literary translation (Newmark 1995: 151)). The English-Serbian translation of risk management terms in banking belongs to the category of non-literary, socio-eco-political and institutional-cultural translation, i.e. specialized translation as the overarching term and notion.
} 
Calque (or loan translation) occurs at the level of lexemes and syntagms when a language borrows an expression form of another and then translates literally each of its elements (Hlebec 2009: 24; Vinay \& Darbelnet 1995: 30-41). A calque can be 'lexical' (respecting 'the syntactic structure of the TL, whilst introducing a new mode of expression') such as the ET book value and its STE knjigovodstvena vrednost and 'structural' (introducing 'a new construction into the TL') such as the ET delivery-versus-payment and its STE isporuka-uzplaćanje (Vinay \& Darbelnet 1995: 30-41). The hyphens found in the English compound terms are usually kept in the calqued Serbian equivalents as shown in Table 3. Moreover, loan translation is a complex translation procedure frequently combined with other procedures such as borrowing (e.g. fer in fer vrednost, repo in repo-stil transakcija, adekvatnost in adekvatnost kapitala, etc.), reordering (e.g. capital adequacy = adekvatnost kapitala, asset-backed commercial paper = komercijalni papir podržan aktivom, debt service coverage ratio $=$ koeficijent pokrivenosti servisiranja duga, etc.) and transposition (e.g. commodity market = robno tržište, wherein the English noun commodity is translated by the Serbian adjective robno). Overall, calque is the most prevalent translation procedure employed in the primary source materials and it accounts for $49.64 \%$ of the STEs examined.

Table 3 The glossary examples of lexical and structural calques

\begin{tabular}{|c|c|c|c|}
\hline English term & $\begin{array}{l}\text { Serbian translation } \\
\text { equivalent - lexical calque }\end{array}$ & English term & $\begin{array}{l}\text { Serbian translation equivalent } \\
\text { - structural calque }\end{array}$ \\
\hline $\begin{array}{l}\text { asset-backed } \\
\text { commercial paper }\end{array}$ & $\begin{array}{l}\text { komercijalni papir podržan } \\
\text { aktivom }\end{array}$ & $\begin{array}{l}\text { counter- } \\
\text { guarantee }\end{array}$ & kontra-garancija \\
\hline banking book & bankarska knjiga & $\begin{array}{l}\text { cross-product } \\
\text { netting }\end{array}$ & netting različitog-pr \\
\hline capital adequacy & adekvatnost kapitala & $\begin{array}{l}\text { delivery-versus- } \\
\text { payment }\end{array}$ & isporuka-uz-plaćanje \\
\hline committed credit line & odobrena kreditna linija & jump-to-default & skok-u-neizvršenje \\
\hline comn & robno tržište & loan-to-value & kredit-prema-vrednosti \\
\hline curre & $\begin{array}{l}\text { tekuća tržišna vrednost; } \\
\text { trenutna tržišna vrednost }\end{array}$ & $\begin{array}{l}\text { payment-versus- } \\
\text { payment }\end{array}$ & plaćanje-uz-plaćanje \\
\hline
\end{tabular}

Literal translation is defined as 'the direct transfer of a SL text into a grammatically and idiomatically appropriate TL text in which the translators' task is limited to observing the adherence to the linguistic servitudes of the TL' (Vinay \& Darbelnet 1995: 30-41). Therefore, literal translation implies the equality between the ST and the TT in terms of the number, type and order of lexical items, as well as the meaning of individual words (Table 4). It is present at the level of simple lexemes (e.g. call = poziv, ceiling = plafon or plafoniranje, etc.), complex lexemes (e.g. ageing = starost, exposure = izloženost, etc.), compound lexemes (e.g. actual loss = stvarni gubitak, auto loan = auto kredit, etc.) and phrasal lexemes (e.g. Undertakings for Collective Investments in Transferable Securities = Preduzeća za kolektivna investiranja u prenosive hartije od vrednosti, etc.). It is noteworthy that the structure of lexical items remains predominantly the same in the TL. However, literal translation can cause various TL inaccuracies either lexicosemantically (the ET model risk, which means 'the risk resulting from a weakness in a model', is literally translated as model rizika with a semantic alteration in Serbian meaning 'a certain model of risk') or morphosyntactically (the ET auto loan is literally translated by the STE auto kredit, which consists of a rare and non-standard combination of two nominative case nouns 
in Serbian). Consequently, literal translation is not as commonplace as borrowing or loan translation and it accounts for $9.21 \%$ of the STEs examined.

Transposition essentially occurs when a part of speech is supplanted by a different one in translation without changing the sense (Vinay \& Darbelnet 1995: 30-41). This common procedure stems from the structural differences between languages and it can be either obligatory or optional. The English compound stress testing (consisting of two nouns) is translated into Serbian as stresni test, wherein the English noun stress is translated by the Serbian adjective stresni. Nevertherless, there are examples of the reverse transposition direction when an English adjective becomes a noun in Serbian (e.g. past due = docnja, reputational risk $=$ rizik reputacije, etc.). Transposition also subsumes other grammar alterations such as a change in noun number (singular to plural or vice versa) (Newmark 1995: 85). The instances of such transposition are observed in the translation of the English plural noun earnings by the Serbian singular noun prihod and the English singular (uncountable) noun risk management by the Serbian plural noun upravljanje rizicima. Transposition (Table 4 ) accounts for $14.73 \%$ of the STEs examined.

Table 4 The glossary examples of literal translation and transposition

\begin{tabular}{|c|c|c|c|}
\hline English term & $\begin{array}{l}\text { Serbian translation } \\
\text { equivalent - literal } \\
\text { translation }\end{array}$ & English term & $\begin{array}{l}\text { Serbian translation } \\
\text { equivalent - transposition }\end{array}$ \\
\hline $\begin{array}{l}\text { actual loss } \\
\text { ageing } \\
\text { auto loan } \\
\text { call } \\
\text { ceiling } \\
\text { exposure } \\
\text { model risk } \\
\text { potential future } \\
\text { exposure }\end{array}$ & $\begin{array}{l}\text { stvarni gubitak } \\
\text { starost } \\
\text { auto kredit } \\
\text { poziv } \\
\text { plafoniranje; plafon } \\
\text { izloženost } \\
\text { model rizika } \\
\text { potencijalna buduća } \\
\text { izloženost }\end{array}$ & $\begin{array}{l}\text { basis risk } n . \\
\text { clearing house } n . \\
\text { commodity risk } n . \\
\text { listed } a d j . \\
\text { market value } n . \\
\text { overnight } a d j . \\
\text { profit margin } n . \\
\underline{\text { reputational risk } a d j .} \text { risk pool } n .\end{array}$ & $\begin{array}{l}\text { osnovni rizik } a d j . \\
\text { klirinška kuća } a d j . \\
\text { robni rizik } a d j . \\
\text { kotira se } v . \\
\text { tržišna vrednost } a d j . \\
\text { preko noći NP } \\
\text { profitna marža } a d j . \\
\text { rizik reputacije } n . \\
\text { rizični pul } a d j .\end{array}$ \\
\hline
\end{tabular}

Modulation is defined as a variation of the SL message in the TL by a change in the point of view. Such change is conspicuous when a literal or even transposed translation results in a grammatically correct utterance, which is considered semantically unsuitable, unidiomatic or awkward in the TL (Vinay \& Darbelnet 1995: 30-41). For instance, the translation of borrower as dužnik, not as zajmoprimalac, involves a change in the point of view because the term borrower implies 'someone who borrows a loan', whereas dužnik means 'someone who owes borrowed money'. Furthermore, modulation can be combined with loan translation (e.g. parent company = firma majka), borrowing (e.g. credit rating $=$ rejting duga) and transposition (e.g. currency risk $=$ kursni rizik) as shown in Table 5 . Modulation is more oblique in comparison with the aforementioned translation procedures and not as frequent in specialized translation, thus accounting for $4.68 \%$ of the STEs examined. 
Table 5 The glossary examples of modulation

\begin{tabular}{ll}
\hline English term & Serbian translation equivalent - modulation \\
\hline borrower & dužnik \\
currency risk & kursni rizik \\
credit rating & rejting duga \\
delinquent & u prestupu \\
lending & kreditni plasman \\
loan-to-value & dug prema vrednosti nekretnine \\
outstanding amount & postojeći iznos \\
parent company & majka-firma; firma majka \\
\hline
\end{tabular}

The contrast between two linguistic systems becomes even more apparent when the same situation has to be described by 'different stylistic and structural methods' in the ST and the TT so as to achieve approximate equivalence at the semantic level (Vinay \& Darbelnet 1995: 30-41). This translation procedure, which is most obvious between languages belonging to entirely distinct language families and cultural spheres, is termed 'equivalence' by Vinay and Darbelnet (although equivalence is only functional because words and phrases translated in this manner have the same function in their respective languages, whereas their forms may differ radically). Equivalence mostly encompasses the domain of proverbs, idioms, clichés and other standard aspects of language (Vinay \& Darbelnet 1995: 30-41). The examples of equivalence in risk management terminology include the translation of receiver as stečajni upravnik, marketability as utrživost and the ETs and their STEs displayed in Table 6. As equivalence implies a form of TL adaptation, it is usually supplemented with other translation procedures such as expansion (e.g. commitment $=$ preuzeta obaveza), reduction (e.g. deposit-taking institution = deponentna institucija), diffusion (e.g. balloon = jednokratna isplata) and condensation (e.g. bill of exchange $=$ menica . . Equivalence accounts for $22.41 \%$ of the STEs examined.

Adaptation bridges cultural gaps when the situation referred to in the source text is not known in the TL culture (Vinay \& Darbelnet 1995: 30-41). Although cultural words are not common in banking genres (as banks operate at the international and global levels), the introduction of cultural SL words into the TL is performed either by borrowing or description and/or definition, i.e. using Newmark's 'descriptive equivalents' (1995: 83). Providing a description or a definition of a new term can be useful during the initial stage of TL incorporation (when the experts are still incognizant of its proper meaning and usage). At a later stage, a descriptive equivalent is preferably supplanted by a loanword or a newlycoined TL term, conforming to the norms of language economy and accuracy. An example of adaptation is the ET workout and its STE naplata loših kredita, which is in fact a descriptive equivalent. Adaptation is frequently combined with other translation procedures such as expansion (e.g. recovery $=$ naplata potraživanja $u$ neizvršenju), reduction (e.g. residential mortgage loan = stambena hipoteka), diffusion (e.g. bid bond = garancija $z a$ učešce na licitaciji) and borrowing (e.g. swaption = opcija da se uđe u svop kamatne stope) as shown in Table 6. Adaptation accounts for $7.32 \%$ of the STEs examined. 
Table 6 The glossary examples of equivalence and adaptation

\begin{tabular}{|c|c|c|c|}
\hline English term & $\begin{array}{l}\text { Serbian translation } \\
\text { equivalent - } \\
\text { equivalence }\end{array}$ & English term & $\begin{array}{l}\text { Serbian translation equivalent } \\
\text { - adaptation }\end{array}$ \\
\hline $\begin{array}{l}\text { account take-over } \\
\text { balloon }\end{array}$ & $\begin{array}{l}\text { uzurpacija računa } \\
\text { jednokratna isplata / } \\
\text { otplata }\end{array}$ & $\begin{array}{l}\text { bid bond } \\
\text { defaulter }\end{array}$ & $\begin{array}{l}\text { garancija za učešće na licitaciji } \\
\text { strana u neizvršenju }\end{array}$ \\
\hline cap & gornji limit & grandfathering & $\begin{array}{l}\text { grandfathering (bez retroaktivnog } \\
\text { dejstva) }\end{array}$ \\
\hline cherry-picking & $\begin{array}{l}\text { odabir najboljeg; } \\
\text { uzimanje najboljeg }\end{array}$ & mortgage loan & kredit obezbeđen nekretninama \\
\hline $\begin{array}{l}\text { claim } \\
\text { commitment }\end{array}$ & $\begin{array}{l}\text { potraživanje } \\
\text { preuzeta obaveza; } \\
\text { obaveza }\end{array}$ & $\begin{array}{l}\text { OTC derivative } \\
\text { outstandings }\end{array}$ & $\begin{array}{l}\text { derivat kojim se trguje na OTC tržištu } \\
\text { neotplaćeni plasman po linijama }\end{array}$ \\
\hline foreclose & pleniti založenu imovinu & past due & dospeo i neotplaćen; kasniti u plaćanju \\
\hline
\end{tabular}

The additional procedures argued by Newmark (1995) (expansion and reduction) and Malone (1988) (diffusion, condensation and reordering) account for the TL adaptation of SL lexical units by altering the number, structure and order of their constituents. Expansion refers to the addition of elements or information in the TL so as to express the SL message more explicitly and accurately (e.g. the ET issuance facility and its STE kreditna olakšica za emitovanje srednjeročnih nota). The added elements are mostly modifiers, prepositions, conjunctions and additional information necessary for semantic disambiguation (the added elements are underlined in the STEs shown in Table 7). Conversely, reduction entails the omission of elements or information from the SL lexical unit in the TL for the purpose of language economy and message conciseness (e.g. the ET custodial services and its STE kastodi). The omitted elements from the ETs are underlined in Table 7.

Table 7 The glossary examples of expansion and reduction

\begin{tabular}{|c|c|c|c|}
\hline English term & $\begin{array}{l}\text { Serbian translation } \\
\text { equivalent - expansion }\end{array}$ & English term & $\begin{array}{l}\text { Serbian translation } \\
\text { equivalent }- \text { reduction }\end{array}$ \\
\hline brokerage & brokerski poslovi & $\underline{\text { cash advance fee }}$ & naknada za avanse \\
\hline close-out & zatvaranje pozicije & committed credit line & obećana linija \\
\hline convertible & konvertibilni instrument & custodial services & kastodi \\
\hline credit loss & gubitak po kreditu & $\underline{\text { debt service coverage ratio }}$ & $\begin{array}{l}\text { koeficijent pokrića } \\
\text { servisiranja }\end{array}$ \\
\hline $\begin{array}{l}\text { equity investment } \\
\text { loan agreement }\end{array}$ & $\begin{array}{l}\text { investicija u akcije } \\
\text { ugovor o kreditu/zaimu }\end{array}$ & $\begin{array}{l}\text { interest rate risk } \\
\text { residential mortgage loan }\end{array}$ & $\begin{array}{l}\text { kamatni rizik } \\
\text { stambena hipoteka }\end{array}$ \\
\hline
\end{tabular}

Two diametrically opposed translation procedures defined by Malone are diffusion and condensation, collectively labelled 'repackaging' (1988: 18). Diffusion occurs when 'a source group $\mathrm{AB}$ is, in any of a variety of ways, unpacked or spread out into a more loosely organized target counterpart' (Malone 1988: 18). For instance, diffusion is evident in the translation of the ET back-testing as testiranje unazad and the ET balloon as jednokratna isplata. In both of these examples, tightly bound words, i.e. a compound and simple lexeme respectively, are translated by a loosely bound phrase consisting of two words (Table 8). Condensation, in contrast, illustrates instances when 'a source string 
is, again in any of a variety of ways, more tightly bound or packed together in the target' (Malone 1988: 18). For instance, the English phrasal lexeme bill of exchange is translated by a Serbian simple lexeme menica (Table 8 ).

Another relevant translation procedure described by Malone is reordering which involves 'a difference in positioning between source and target elements' (1988: 18). Its necessity in translation stems from the morphosyntactic constraints of the TL, especially when the two languages (such as English and Serbian) belong to distinct language families (e.g. the ET capital investment and its STE investiranje kapitala). This procedure regularly complements calques as displayed in Table 8 . The most prevalent additional translation procedure recorded in the STEs examined is reordering $(24.59 \%)$, followed by diffusion (13.46\%), expansion (10.52\%), reduction (3.67\%) and condensation (2.19\%).

Table 8 The glossary examples of diffusion, condensation and reordering

\begin{tabular}{|c|c|c|c|c|c|}
\hline $\begin{array}{l}\text { English } \\
\text { term }\end{array}$ & $\begin{array}{l}\text { Serbian translation } \\
\text { equivalent - } \\
\text { diffusion }\end{array}$ & English term & $\begin{array}{l}\text { Serbian } \\
\text { translation } \\
\text { equivalent - } \\
\text { condensation } \\
\end{array}$ & English term & $\begin{array}{l}\text { Serbian translation } \\
\text { equivalent - } \\
\text { reordering }\end{array}$ \\
\hline $\begin{array}{l}\text { capital } \\
\text { relief }\end{array}$ & $\begin{array}{l}\text { smanjenje zahteva } \\
\text { za kapitalom }\end{array}$ & charge-off & $\begin{array}{l}\text { otpis; } \\
\text { terećenje }\end{array}$ & $\begin{array}{l}\text { asset } \\
\text { management }\end{array}$ & $\begin{array}{l}\text { upravljanje } \\
\text { aktivom }\end{array}$ \\
\hline $\begin{array}{l}\text { credit- } \\
\text { worthiness }\end{array}$ & $\begin{array}{l}\text { kreditna } \\
\text { sposobnost }\end{array}$ & $\begin{array}{l}\text { bill of } \\
\text { exchange }\end{array}$ & menica & $\begin{array}{l}\text { asset-backed } \\
\text { commercial } \\
\text { paper }\end{array}$ & $\begin{array}{l}\text { komercijalni papir } \\
\text { podržan aktivom }\end{array}$ \\
\hline floor & donji limit & $\begin{array}{l}\text { perfected } \\
\text { security } \\
\text { interest }\end{array}$ & $\begin{array}{l}\text { obezbeđen } \\
\text { interes }\end{array}$ & capital market & tržište kapitala \\
\hline kickback & tajna provizija & rolled over & refinansiran & capital adequacy & $\begin{array}{l}\text { adekvatnost } \\
\text { kapitala }\end{array}$ \\
\hline
\end{tabular}

The overall percentage share computed for each translation procedure employed in the glossary (Figure 1) indicates its prevalence individually and in combination with other procedures in the following order: calque $(49.64 \%)$, borrowing $(32.45 \%)$, reordering $(24.59 \%)$, equivalence $(22.41 \%)$, transposition (14.73\%), diffusion (13.46\%), expansion

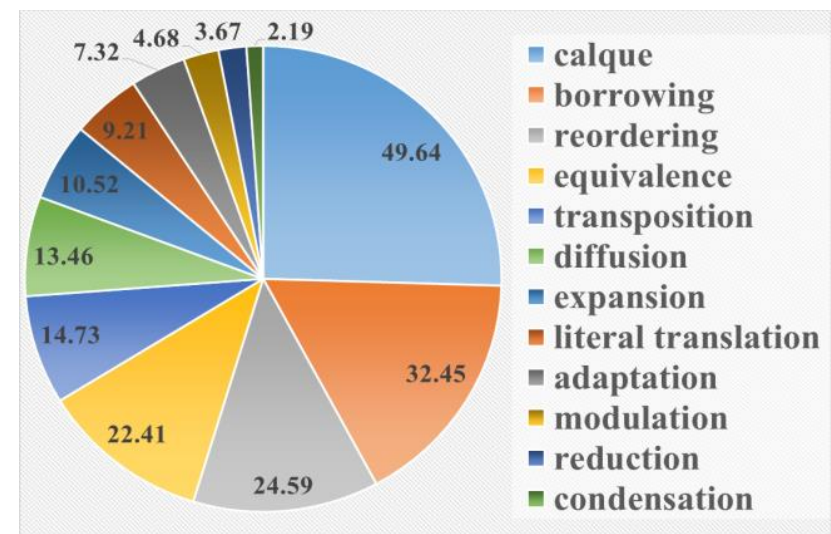

Fig. 1 The overall prevalence (\%) of each translation procedure in the glossary computed individually and in combination with other procedures 
$(10.52 \%)$, literal translation $(9.21 \%)$, adaptation $(7.32 \%)$, modulation $(4.68 \%)$, reduction $(3.67 \%)$ and condensation $(2.19 \%)$. The results obtained reflect the underlying trends in the specialized English-Serbian translation of risk management terms in banking, serving as reference guidelines for linguists, lexicographers and translators in their future research and practice.

\section{CONCLUSION}

The purpose of this paper was to describe the process of developing an English-Serbian glossary of risk management terms in banking with an emphasis on the specialized translation procedures utilized therein. Upon completion of the source material content and contrastive analysis, a corpus of 513 English terms (ETs) and 859 Serbian (one-to-one and/or one-to-many) translation equivalents (STEs) was collated and ethnographically verified at Vojvođanska Bank in order to achieve a triangulation of the data sources and research methods. The English-Serbian Glossary of Risk Management Terms in Banking presented in this paper is designed as a subject-specific advanced guide for working professionals engaged in the fields of banking and finance. The glossary will indubitably facilitate and enhance business communication within and across both profit-motivated enterprises and non-profit organizations, as well as the banking and financial sectors as a whole. Moreover, it could be the predecessor to a large-scale prospective volume such as an English-Serbian dictionary of risk management terms in banking. The glossary is available in entirety and with open access on the self-created web page ESGRMTB ${ }^{5}$.

The translation procedures argued by Jean-Paul Vinay and Jean Darbelnet in their seminal work Comparative Stylistics of French and English (1995) (namely borrowing, calque, literal translation, transposition, modulation, equivalence and adaptation) incorporate the fundamental principles of translation and form the basis of specialized English-Serbian translation in the glossary. These procedures are frequently used individually and/or in combination either with each other or additional (supplementary and complementary) procedures as argued by other authors, namely Newmark (expansion and reduction (1995: 90)) and Malone (diffusion, condensation and reordering (1988:18)). The most prevalent translation procedure employed in the glossary is calque, followed by borrowing, reordering, equivalence, transposition, diffusion, expansion, literal translation, adaptation, modulation, reduction and condensation. The results obtained reflect the underlying trends in the specialized English-Serbian translation of risk management terms in banking, serving as reference guidelines for linguists, lexicographers and translators in their future research and practice.

\section{SOURCES}

Englesko-srpski ekonomsko-finansijski rečnik. Simurdić, Biljana. Novi Sad: CUP NS, 2004

Financial Dictionary Investopedia. 〈http://www.investopedia.com/dictionary/〉21. 2. 2016.

Glossary of Insurance and Risk Management Terms. International Risk Management Institute (IRMI), 2016. 〈https://www.irmi.com/free-resources/insurance-glossary〉 17. 1. 2016.

\footnotetext{
${ }^{5}$ ESGRMTB: The English-Serbian Glossary of Risk Management Terms in Banking https://docs.google.com/document/d/1J_3a6FAB0A1vdgTncjDgUydnIy1SvlUuIMvhVBDyXi0/edit?pref=2\&pli=1
} 
InvestorWords. 〈http://www.investorwords.com/〉 21. 2. 2016

Online Business Dictionary. 〈http://www.businessdictionary.com/〉 20. 2. 2016.

Poslovni rečnik: englesko-srpski srpsko-engleski (2nd ed.). Cvejić, Miroslava. Belgrade: Prosveta, 2006.

The Dictionary of Financial Risk Management. Gastineau, Gary L., and Mark P. Kritzman. Pennsylvania (US): Frank J. Fabozzi Library, 1999.

The Free Dictionary: Dictionary, Encyclopedia and Thesaurus. «ttp://www.thefreedictionary.com/> 23. 2. 2016.

\section{REFERENCES}

Allen, S., (2013), Financial Risk Management (Second Edition), New Jersey, USA: John Wiley \& Sons.

Basturkmen, H., (2010), Developing Courses in English for Specific Purposes, Basingstoke, UK: Palgrave Macmillan.

Bell, R. T., (1991), Translation and Translating: Theory and Practice, London: Longman.

Belcher, D. (ed.), (2009), English for Specific Purposes in Theory and Practice, Ann Arbor, MI: University of Michigan Press.

Bessis, J., Risk Management in Banking (4 ${ }^{\text {th }}$ Edition). Chichester, UK: John Wiley and Sons Ltd, 2015.

BCBS, (2006), Basel II: The International Convergence of Capital Measurement and Capital Standards: A Revised Framework, Basel: Bank for International Settlements.

BCBS, (2011) Basel III: A Global Regulatory Framework for More Resilient Banks and Banking Systems Revised Version, Basel: Bank for International Settlements.

BCBS, (2013), Basel III: The Liquidity Coverage Ratio and Liquidity Risk Monitoring Tools, Basel: Bank for International Settlements.

BCBS, (2014), Basel III: The Net Stable Funding Ratio, Basel: Bank for International Settlements.

Cao, D., (2007), Translating Law, Clevedon, UK: Multilingual Matters.

Carey, M., and R. M. Stulz., (2007), The Risks of Financial Institutions, Chicago, USA: University of Chicago Press.

Gramling, A. A., (2001), 'Internal Control Integrated Framework (Coso Report)', In: Encyclopedia of Business and Finance. Ed. Burton S. Kaliski. Vol. 2. New York: Macmillan Reference USA, 487-90.

Härle, P. et al., (2015), The Future of Bank Risk Management, London, UK: McKinsey \& Company.

Hlebec, В., (2009): Хлебец, Б., (2009), Преводилачке технике и поступии, Београд: ЕБГ д.о.о.

Ho, T., and S. B. Lee, (2006), Encyclopedia of Finance, Eds. Cheng-Few Lee and Alice C. Lee. USA: Springer, 491-500.

Hull, J. C., (2015), Risk Management and Financial Institutions $\left(4^{\text {th }}\right.$ Edition), Hoboken, New Jersey, USA: McKinsey \& Company.

Hyland, K., (2006), English for Academic Purposes, London: Routledge.

Kovačević, I. (ed.), (2007), Bazel II: Međunarodna saglasnost o merenju kapitala i standardima kapitala, Belgrade: Jugoslovenski pregled.

Kovačević, I. (ed.), (2012), Bazel III: Globalni regulatorni okviri i standardi, Belgrade: Jugoslovenski pregled.

Kovačević, I. (ed.), (2014), Bazel III: Međunarodni okvir za merenje rizika likvidnosti, standarde $i$ monitorisanje, Belgrade: Jugoslovenski pregled.

Lauer, K., Dias, D., and M. Tarazi. Bank Agents: Risk Management, Mitigation, and Supervision. 2011. 〈http://www.cgap.org/publications/bank-agents-risk-management-mitigation-and-supervision〉 7. 4. 2017.

Malone, J. L., (1988), The Science of Linguistics in the Art of Translation: Some Tools from Linguistics for the Analysis and Practice of Translation, Albany, NY: State University of New York.

Munday, J., (2001), Introducing Translation Studies: Theories and Applications, London: Routledge.

NBS. Risk Management in Banking. The National Bank of Serbia, 2016. 〈http://www.nbs.rs/internet/english/ 55/55_6/> 20. 2. 2016.

Newmark, P., (1995), A Textbook of Translation. New York: Phoenix ELT, 1995.

Roberts, R. P., (1995), 'Towards a Typology of Translations', Hieronymus Complutensis 1: 69-78.

Rogers, M., and G. Anderman. (eds.), (2003), Translation Today: Trends and Perspectives. Clevedon, UK: Multilingual Matters.

Schäffner, C. (ed.), (2004), Translation Research and Interpreting Research: Traditions, Gaps and Synergies, Clevedon, UK: Multilingual Matters.

Snell-Hornby, M., (1995), Translation Studies: An Integrated Approach, Amsterdam: John Benjamins Publishing Company.

St John, M. J., (1996), 'Business is booming: Business English in the 1990s', English for Specific Purposes 15: $3-18$. 
Starfield, S., (2010), 'Fortunate travellers: Learning from the multiliterate lives of doctoral students', In: M. Walker and P. Thomson (eds.), The Routledge Doctoral Supervisor's Companion. London: Routledge, $138-46$.

Uyemura, D. G., and D. R. van Deventer, (1993), Financial Risk Management in Banking, Chicago, USA: BAIF (Bank Administration Institute Foundation).

Vinay, J.-P., and J. Darbelnet, (1995), Comparative Stylistics of French and English, Trans. J. Sager and M-J. Hamel, Amsterdam and Philadelphia: John Benjamins.

\section{ENGLESKI JEZIK ZA POSLOVNE NAMENE: STRUČNO PREVOĐENJE U PROCESU SASTAVLJANJA ENGLESKO-SRPSKOG GLOSARA TERMINA IZ OBLASTI UPRAVLJANJA RIZICIMA U BANKARSTVU}

Primarni cilj ovog rada je da opiše proces sastavljanja englesko-srpskog glosara termina iz oblasti upravljanja rizicima u bankarstvu s naglaskom na stručnim prevodilačkim postupcima primenjenim $u$ glosaru. Nakon kontrastivne analize sadržaja izvorne građe (uz pomoć programa za kvalitativnu analizu podataka Atlas.ti 7) objedinjen je korpus od 513 engleskih termina (ET) i 859 srpskih (jednostrukih i/ili višestrukih) prevodnih ekvivalenata (SPE) koji su etnografski verifikovani u Vojvođanskoj banci s namerom da se ostvari triangulacija izvora podataka i istraživačkih metoda. Stručno prevođenje odabranih engleskih termina sa engleskog na srpski jezik se zasniva na fundamentalnim prevodilačkim postupcima koje su definisali Žan-Pol Vine (Jean-Paul Vinay) $i$ Žan Darbelne (Jean Darbelnet) (1995) (pozajmljivanje, kalkiranje, doslovno prevođenje, transpozicija, ekvivalencija i adaptacija) kao i dodatnim (suplementarnim i komplementarnim) postupcima koje su definisali Piter Njumark (Peter Newmark) (1995) (ekspanzija i redukcija) i Džozef Malon (Joseph Malone) (1988) (difuzija, kondenzacija i permutacija). Ukupna zastupljenost svakog prevodilačkog postupka primenjenog u glosaru je izražena pojedinačno $i$ u kombinaciji $s$ drugim postupcima: kalkiranje $(49,64 \%)$, pozajmljivanje (32,45\%), permutacija $(24,59 \%)$, ekvivalencija $(22,41 \%)$, transpozicija (14,73\%), difuzija (13,46\%), ekspanzija (10,52\%), doslovno prevođenje $(9,21 \%)$, adaptacija $(7,32 \%)$, modulacija $(4,68 \%)$, redukcija $(3,67 \%)$ i kondenzacija $(2,19 \%)$. Ostvareni rezultati ilustruju osnovne tendencije $u$ stručnom prevođenju termina iz oblasti upravljanja rizicima $u$ bankarstvu sa engleskog na srpski jezik $i$ nude referentne smernice lingvistima, leksikografima $i$ prevodiocima za budući praktični i istraživački rad. Predmetni glosar je dostupan u celosti $i$ sa slobodnim pristupom na veb-stranici ESGRMTB ${ }^{6}$ koju su samostalno kreirali autori.

Ključne reči: engleski jezik za poslovne namene, englesko-srpski glosar, stručno prevođenje, upravljanje rizicima, bankarstvo

\footnotetext{
${ }^{6}$ ESGRMTB: The English-Serbian Glossary of Risk Management Terms in Banking https://docs.google.com/document/d/1J_3a6FAB0A1vdgTncjDgUydnIy1SvlUuIMvhVBDyXi0/edit?pref=2\&pli=1
} 